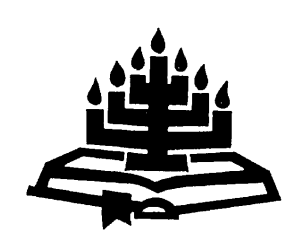

\title{
An evangelical voice in Africa: the worldview background of the theology of Tokunboh Adeyemo (1 October 1944-17 March 2010) ${ }^{1}$
}

\author{
B.J. van der Walt \\ School of Philosophy \\ Potchefstroom Campus \\ North-West University \\ POTCHEFSTROOM
}

E-mail: benniejvanderwalt@gmail.com

\begin{abstract}
An evangelical voice in Africa: the worldview background of the theology of Tokunboh Adeyemo (1 October 194417 March 2010)

Africa was blessed with a son of the calibre of Dr Tokunboh Adeyemo. Since he only recently passed away, we do not yet have (as far as the author is aware) an assessment of the legacy of this eminent Christian leader. This article is the first preliminary evaluation written from a reformational worldview perspective.

The set-up of the investigation is as follows: Firstly, a brief outline is given of his life history, especially his training in the Evangelical tradition. Then, the décor (the overall situation of African Christianity) that was the background against which he lived and worked is painted. Thirdly, it is followed by the strengths and weaknesses of Evangelical Christianity of which Adeyemo was a representative. Fourthly, it is indicated how Adeyemo thought in line with post-Lausanne Evangelicalism. In the fifth place a preliminary worldview evaluation of his legacy is given. To assist possible future research a bibliography of his most important publications concludes the investigation.
\end{abstract}

1 Reworked text of a paper delivered at the Koers-75 International Conference, April 2011 at Potchefstroom. 
Opsomming:

'n Evangeliese stem in Afrika: die lewensbeskoulike agtergrond van die teologie van Tokunboh Adeyemo (1 Oktober 1944-17 Maart 2010)

\begin{abstract}
Afrika was geseënd met 'n seun van die kaliber van $d r$. Tokunboh Adeyemo. Aangesien hy onlangs oorlede is, beskik ons nog nie (sover die skrywer weet) oor 'n waardering van die nalatenskap van hierdie voortreflike Christen Afrikaleier nie. Hierdie artikel is die eerste voorlopige evaluering vanuit 'n reformatoriese lewensbeskoulike hoek.

Die ondersoek ontwikkel soos volg: Eerstens word 'n kort oorsig van sy lewensgeskiedenis gebied, veral ten opsigte van sy opleiding in die evangeliese tradisie. Dan word die dekor (die algemene toestand van die Afrika-Christendom) geskets - die agtergrond waarteen hy gelewe en gedink het. Dit word, in die derde plek, gevolg deur 'n kort analise van die sterk- en swakpunte van die evangeliese Christendom waarvan Adeyemo 'n verteenwoordiger was. In die vierde plek word kortliks aangetoon hoe Adeyemo, in ooreenstemming met die post-Lausanne evangelikalisme, gedink het. Vyfdens word ' $n$ voorlopige waardering van sy nalatenskap gegee. Die artikel word (met die oog op hulp aan toekomstige navorsers), afgesluit met 'n bibliografie van sy belangrikste publikasies.
\end{abstract}

\title{
1. Introduction: importance, limitation and set-up
}

By way of introduction I first give a motivation for this contribution, its limitations and an overview of the development of the article.

\subsection{Motivation for the importance of this contribution}

Since it is not usually the custom to devote a full article to the life and theology of one person, I start with a short motivation.

\subsubsection{An eminent Christian leader in Africa}

Without doubt Adeyemo was a leader of considerable stature something that has become a rarity in modern-day Africa. Moreover he was an overtly Christian leader - even rarer on the continent. Furthermore, he was a Christian who loved the Word of God and wanted to submit himself to it unconditionally. In this respect his evangelical faith was very close to the reformational convictions that also characterise In die Skriflig. Fourthly, surrounded by all kinds of African theologies, he made a significant contribution to theological science on the African continent from an evangelical perspective. 


\subsubsection{Institutional reasons}

Apart from these more general reasons, this article was also written with institutional motivations. Since 1983 Adeyemo had close ties with the Institute for Reformational Studies (1962-1999), as well as with the then Potchefstroom University for Christian Higher Education (PU for CHE). As long ago as 1975 his predecessor at the AEA, Dr. Byang Kato, delivered a lecture at the First International Conference of Reformational Institutions for Christian Higher Education in Potchefstroom (cf. Kato, 1976). In 1994 the PU for CHE awarded a Th.D. honoris causa to Adeyemo (cf. Van der Walt, 1994). And finally, in 2008 he spent several months doing research for a book on Systematic Theology for Africa at the Potchefstroom Theological School of the Reformed Churches in South Africa.

\subsubsection{Personal reasons}

In addition, the author would like to mention his own personal reasons for paying homage to this man. During the years of apartheid, black people (even those of the stature of Adeyemo) had difficulty in finding lodging in Potchefstroom. So, this brother had to stay in the author's house - which proved to be a blessing to our whole family.

Even after the apartheid era we retained contact and publications were exchanged. The fly leaf inscriptions in two of these read as follows: "Bro. Bennie, may your vision of a better Africa be realized in our generation" (Adeyemo, 1997b), and "Beloved prof. Bennie, you have been an inspiration to me and to many young African scholars. I salute you and wish you God's richest blessings. Keep your vision and passion for Africa's renaissance alive!" (Adeyemo, 2009). (Our last contact was his moving prayer for healing when we were both seriously ill.)

\subsubsection{Additional research}

In addition to the above-mentioned reasons, as far as the author knows, no existing scholarly appreciation of Adeyemo's work exists. As a basis for such an evaluation Breman (1996b:594-551) only provides a bibliography of his writings up to 1996 and her study is also not widely available or known. (For this reason his writings are listed in a separate attached bibliography.) 


\subsection{Two limitations}

It is impossible to describe and evaluate Adeyemo's evangelical theology for Africa in one article. (I hope that other researchers will add to it.) This article is intended as an initial investigation of the broader, underlying worldview background of his theology. This is done from the perspective of a reformational worldview and philosophy.

Although mention is made of Adeyemo's "theology" it has to be pointed out that unfortunately he could not finish his manuscript on his systematic theology (specifically for Africa) before his death. His theological points of departure therefore have to be inferred from his dissertation, and many other publications on diverse subjects - like the ears of a hippopotamus showing above the water.

\subsection{Set-up}

After a brief summary of his life history, the investigation will be presented as follows. Firstly, the background of African Christianity is sketched. Then follows a short characterisation of the Evangelical Christendom of which he was a distinct representative. Subsequently, it is shown how Adeyemo's theological thinking was in conformity with post-Lausanne Evangelicalism. This is followed by a worldview evaluation. Finally, as an aid to future researchers who would want to study his theology in detail, a bibliography is added of his most important works.

\section{A short biography}

Since Adeyemo (cf. 1979a:97-99; 1997a:112-114) himself gave a brief life history and it was supplemented at his funeral (cf. Cole, 2010; Adeyemo, 2010:1), there is no need to give it in full detail here. (For more details cf. also Van der Walt, 1983:10-12; 1994 \& 2009:75-85.)

\subsection{Early years}

Adeyemo was born on 1 October 1944 into a rich Yoruba Muslim family of noble descent. His father also had other wives. His mother left him after the birth of two children (Adeyemo was the elder) and married a second husband with whom she had six more children in total four sons and four daughters. The first education the young Tokunboh received was in a Muslim school where he memorised the entire Koran over the course of three years. With the exception of a 
pilgrimage to Mecca he fulfilled all the requirements of the Muslim faith.

He attended a teacher's college, finishing his teacher's diploma in 1962 and later became prinicipal of a school. However, his ultimate aim was a political career: he planned to be the president of Nigeria within ten years! (This was no impossible ideal, since he came from a royal family. His uncle also was a parliamentarian and Tukunboh himself was the local secretary of the specific political party.)

\subsection{Conversion}

His family was rich and he had a promising future, yet the amibitious young man was not happy. Tokunboh relates how he was continuously plagued by two questions: What is the purpose of life? and, What happens when you die? He even became a member of a group of "Free thinkers" (whose leader was trained in Moscow) in an effort to find an answer to these profound questions.

One of the teachers at his school invited him to accompany him to church in 1962 - something that is forbidden to a Muslim. The first thing that struck him at this service was the joy of the people. He had to find out the reason for this while he himself was so unhappy. For four years he both attended the church and kept up his duties as a Muslim. (He admits he was motivated more by the beautiful girls in the church!) While he had everything, he made no progress with his ten year plan and later on became so depressed that he contemplated suicide.

In 1966 a South African missionary (Rev. E. White) conducted revival services for a week in a tent in his town and preached from the well-known John 10:10. (Christ came so that we can have life abundantly.) After the service the preacher prayed for Adeyemo and at the age of 22 he repented his sins, confessed his faith, and was baptised. His questions about the purpose of life had been answered: he realised that the Lord had a plan with his life and his fear of death had been allayed. He experienced a great hunger for the Word of God - a hunger that would never be satisfied all through his life. (After his baptism he studied the Bible in its entirety every year.)

However, he had to pay a high price for his conversion to the Christian faith: rejection and disinheritance by his family. Later the Lord, however, used him to win over his mother, brothers and sisters to the Christian faith. In 1967 he became an evangelist and in 1971 
he became a member of the Evangelical Churches of West Africa (ECWA) at Igbaja (Nigeria). In 1977 he was ordained in the USA in the Church of the Open Door. Later, when he became the general secretary of the Association of Evangelicals in Africa (AEA) (with its head office in Kenya), he became a member and served for years as an elder of the Nairobi Pentecostal Church.

\subsection{Advanced study}

After his conversion he first studied for three years at a Theological School (Igbaja Theological Seminary) of the Sudan Interior Mission in Ibadan. From September 1973 he studied at the Talbot Seminary in La Mirada, California and in January and May 1976 he was awarded an M.Div. (cf. Adeyemo, 1976a) and a Th.M. degree (cf. Adeyemo, 1976b). In December 1977 he also completed a D.Th. degree at Dallas Theological Seminary, Texas - an eminent American Evangelical Seminary (cf. Adeyemo, 1978). In 1979 these were followed by a Ph.D. at the University of Aberdeen, Scotland (cf. Adeyemo, 1979b). From the above information on Adeyemo's education it is clear that he was thoroughly trained in the Evangelical worldview and theology.

\subsection{The Association of Evangelicals in Africa}

As early as 1977 Adeyemo was elected acting general secretary of the Association of Evangelicals in Africa and Madagascar (later merely known as AEA since Madagascar was considered a part of Africa), and from 1979 to 2002 he served as permanent general secretary. His service in this organisation can be regarded as his life mission. In this way he not only united approximately 50 million Evangelical Christians in Africa, but also rendered a much broader, world-wide service (more about this to follow).

\subsection{Final contributions}

After retiring from the AEA in 2002, Adeyemo made two more significant contributions. The first in 2003, was to establish the Center for Biblical Transformation in Nairobi. Its purpose was to train African leaders one by one to make a difference on the continent (cf. Adeyemo, 2006d).

The second was his contribution as general editor of the Africa Bible Commentary (comprising 1585 pages), while he himself also wrote the commentaries on four Bible books (cf. Adeyemo, 2006a). With this work African Christendom reached a special milestone. 
Unfortunately, as was mentioned above, his last, most important work, a systematic theology written specifically for Africa, was left incomplete with only 15 of the about 30 chapters intended having been finished.

\subsection{Personality}

According to numerous witnesses Adeyemo was a serious, faithful, humble, loving, self-sacrificing, purposeful, hard-working person - in all respects an example to the leaders of Africa.

Above all he was a devout Christian who lived praying and studying the Bible. His wife, Ireti (cf. Adeyemo, 2010:10), relates that his motto was "Without prayer first, no breakfast", or that he often said: "The birds may not praise God before me in the morning." He therefore got up before the crack of dawn to speak to his "Dad". After that he studied his Word for at least an hour. Then he went jogging and often read some more - sometimes for three to four hours altogether. He was never in a hurry in his personal communion with the Lord and his daily quiet time influenced his whole life.

\subsection{Homage}

As a result of prostate cancer this excellent man died on 17 March 2010 in Nairobi. Adeyemo left behind his wife, Ireti Adeyemo (née Ayelaagbe) whom he married in 1981, and two sons. Doubtless he was one of the giants in the history of Christianity in Africa. (In one of the many e-mail tributes to him he is called a modern-day Tertullian - more about this to follow). He was one of Africa's most dynamic and inspiring leaders. Not only did he uncover incompetent, corrupt, selfish, greedy leadership as the number one cause of the serious predicament our continent finds itself in, he also set the right example with his own life, and rejected their perverted enjoyment of power (cf. Adeyemo, 1993a; 2006d \& 2009). His life motto was the well-known text from Sachariah 4:6b "'not by might nor by power, but by my Spirit,' says the LORD Almighty".

Tributes came in from other parts of the world too, indicating that he served not only the Christians of Africa, but worldwide in various ways. At the end of his earlier self-written life history (cf. Adeyemo, 1979a:99) he said himself that it is not important how long one lives, but what one does with the short while that God grants one (cf. Eph. $5: 16)$. 
The most striking tribute is the one in which his demise was likened to the fall of an Iroko tree (chlorophora exelsa), a tree that is indigenous to the west coast of Africa and Nigeria. (The wood looks like South African teak, having the same colour and durability.)

Subsequently, it is important to make a short study of what African Christianity looked like in which this servant of the Lord had to fulfil his calling. The writer is aware of the fact that the history of Christianity in Africa may not be isolated from the intricate constellation of political, social, economic and cultural circumstances on the continent. However, we do not have the space to explore these. Apart from numerous publications by Adeyemo himself that afford an overview, the interested reader is referred to faithful descriptions like those by Fowler (1995), Helleman and Ahima (2004), Kinoti (1994a; 1994b), Monsma (2006), Shorter and Onyancha (1997), and Turaki (1997) - on p. 33-37 Turaki provides a summary of the serious problems of Africa.

\section{The African context}

We first look at the development of Christianity in Africa in general, and secondly, at the African theologies.

\subsection{The growth of Christianity}

African Christianity, as the readers will know, is much older than that of the West. The Coptic and Ethiopian Churches, which are still in existence today, are some of the oldest churches in the world. In subsequent centuries Christian thinkers from North Africa like Tertullian, Origin, Clements and Augustine made important contributions even to Western Christianity (cf. Oden, 2007).

After this golden age in the north of Africa there was a long period in which little mission took place. Even the missionary efforts of the Portuguese (1450-1750) were limited mainly to a few coastal areas.

During the nineteenth century, however, great missionary activities were launched from Western countries, and subsidiary churches of all the mainstream churches came into being in the African interior. Since the beginning of the twentieth century numerous so-called independent or indigenous churches came into existence, which afforded a bigger role to their own traditional African culture (cf. Hayes, 1998). A subsequent development was the rapid growth (since approximately 1970) of the evangelical, charismatic pentecostal churches (cf. Anon., 2008; Möller, 1998 \& Theron, 1998). 
Here we could also distinguish three phases: the arrival of the Assemblies of God and the Apostolic Faith Mission, the influence of Neo-Pentecostalism from the USA after the Second World War, and the growth after this of an indigenous African Pentecostalism (cf. Gifford, 2004). Elsewhere Gifford (1998:314) states: "The Evangelical sector of Christianity shades into the Pentecostal, and by the late 1980 was losing out heavily to the burgeoning charismatic sector ....". This also led to another shift within African Christianity. After independence, during the euphoria of the sixties and seventies of the previous century, African theologians spent much time accommodating traditional African culture and religion in Christianity. Today, however, under the influence of the Pentecostal Charismatic faith imported from the West, the traditional is often looked down on and ignored (cf. Gifford, 1998:325; AEAM, 1984).

As previously mentioned Adeyemo also found his spiritual home in such a pentecostal congregation in Nairobi. He also regarded the rapid growth of charismatic pentecostal churches as a strength of African Christianity (cf. Adeyemo, 1994b:7-8).

The enormous growth of Christianity in Africa and other southern parts of the world today (while it is waning fast in Europe) is an acknowledged fact. Today, Sub-Sahara is home to one out of every six of the total number of Christians in the world - approximately 350 million (cf. Jenkins, 2002 \& 2006).

From this overview the pluriform, almost indeterminable character of Christianity in Africa will have become clear. It literally consists of thousands of churches and sects in addition to other religions, like traditional African religions and Islam.

However, this phenomenal growth in numbers does not necessarily mean development in depth. Gifford (1998), for instance, points out the tremendous impact everywhere in Africa of the "gospel of health and wealth", imported mostly from the USA. Monsma (2006:xii) asks why Christianity does not have a greater influence for the better in parts of the world like Africa. According to him, it is caused by the fact that Western missionaries only brought the gospel to the people, baptised them, and taught them to read the Bible. The second part of the mandate in Matthew 28:20 "teaching them to obey everything I have commanded you", has been neglected - in other words how to practice the gospel and apply it to everyday problems. Overdulve (1994:54) is of the opinion that one of the most serious causes of the genocide in Rwanda was that the church was 
too busy with personal conversion and did too little to fight structural social injustices.

From his evangelical perspective Adeyemo also wanted to work towards greater depth. In a preface Adayemo (1984d:vii \& viii) asks for instance where the church is while the continent of Africa is bleeding. Due to their huge numbers Christians could have had an enormous impact in all sectors of society, "but this is not so". Later on he states (cf. Adeyemo, 1997a:8) that Christianity in Africa is like a huge river that is sometimes a mile broad but only an inch deep ("shallow in doctrine in the light of its massive numerical growth"). To obtain more depth, evangelical theology had to play a significant role. Kinoti, (1994b:25) also warns that the rapid growth of Christianity could be like the seed in the parable of Matthew 13:5, 6 - because of the shallow soil and a lack of good nourishment it could easily wither just as rapidly.

\subsection{An overview of African theologies}

In the same way that Christianity in Africa is almost impossible to oversee, a great diversity of theological tendencies exist, some of Western origin, others more indigenous. Parratt (1995) and Schreiter (1992) offer the reader an idea of the complexity of the theological scene in Africa.

Bediako (1992) can be an aid in finding your way in this "jungle". He takes as a point of departure the viewpoints of various early Christian thinkers (Tatian, Tertullian, Justin and Clement) on the Graeco-Roman culture of their times, and according to these he makes a classification of the theological views of some leading twentieth century African theologians. Just as Tatian and Tertullian took an antithetical stand on heathen philosophy and religions, there are some contemporary African theologians (although they are a minority) who emphasise the discontinuity between the Christian faith and the traditional African religions and cultures. The great majority of theologians, however, are in line with a synthesis - as favoured earlier by Justin and Clement - pleading for various degrees of continuity between the gospel and traditional African beliefs.

Incidentally, it is a pity that Bediako did not investigate a third possibility as well. In addition to isolation and accommodation there is also the possibility of transformation in a reformational theology. 
What is important, however, is the way Bediako categorises the evangelical viewpoint. Probably because Adeyemo was still alive, Bediako says nothing about Adeyemo's theology. From the way he classifies Byang Kato (1936-1975), Adeyemo's predecessor at the $A E A$, we can nevertheless infer how he would have regarded Adeyemo's theology. According to Bediako (1992:386-425) Kato was a modern-day Tertullian.

Byang Kato came to embody the very antithesis of the basic positions enunciated by the African theologians ... Virtually everything he wrote was intended as a reaction to, and a rebuttal of, much that went to constitute the 'African theology' of the last two decades. (Bediako, 1992:386.)

What was Adeyemo's own view amidst the current theologies of his time, which were mostly of a synthetic nature? The answer has to be sought in his evangelical background - the next main point of this investigation.

\section{The evangelical worldview background to Adeyemo's theology}

Much has been published in recent decades on the evangelical worldview and theology. From this it becomes evident that the word evangelical can include a broad spectrum of opinions. In this typification the author was led by the sources at his disposal (cf. Van der Walt, 1995; König, 1998; Klein, 1998; as well as the detailed bibliography in Pearcey, 2004:458-465 for details).

\subsection{Background and typification}

Pearcey (2004:251 ff. \& 295 ff.) provides a good historic background of the origin and development of this movement in the USA. According to her this group of Christians today forms the largest and most active component of religious life in the USA. According to Jenkins (2002) the "Evangelicals" also is the group with the fastest growth in Africa, Asia and Latin America.

For the purposes of this investigation its main features deserves more attention than its growth. According to Pearcey (2004:257) Evangelicals put less emphasis on official church creeds and dogmas, and more on the subjective, emotional individual conversion and experience of the Christian faith. In their theology great emphasis is put on the authority of the Scriptures (instead of confessional creeds). 
The most important characteristic of evangelical theology, however, is their "double-storeyed" way of thinking (cf. Pearcey, 2004:322323). Reality is (mostly subconsciously) divided into natural (secular) and supernatural (sacred) domains. The Christian religion is restricted to the supernatural or private domain of the individual, family and church. In the natural or public sphere (e.g. the political, economic, social and scientific domain) the Christian faith has no distinct place. Therefore the "evangelical mind" implies a dualistic view instead of an integral and holistic view that sees all of life as service to God. (For a historic overview of the development of this two realm doctrine since early Christian thought and for a Scriptural critique of it, cf. Van der Walt, 2001:1 ff.)

\subsection{Tension between evangelical and ecumenical Christians}

During the leadership of Kato and Adeyemo in the AEA the scenario of Christianity in Africa was determined by two great factions within the Christendom. Internationally there were on the one hand the World Council of Churches (WCC), and on the other hand the World Evangelical Fellowship (WEF). On African soil they were represented by on one side, the All Africa Conference of Churches (AACC) and the other, by the Association of Evangelicals in Africa (AEA). Simply put: on the one hand the "Ecumenicals" (Ec.) and on the other the "Evangelicals" (Ev.). On the face of it they adhered to radically diverging theologies (cf. Van der Walt, 1995 for a characterisation of each).

The Ev. emphasise a personal relationship with God (e.g. in conversion, prayer, Bible study), in other words the "vertical" dimension while the Ec. stress social relationships, in other words the "horizontal" dimension. The first is concerned with the church as church, and for the other the church has to be there for the sake of the world, otherwise it is irrelevant. The former sees redemption primarily as redemption from individual sins; the latter primarily as liberation from unjust, oppressive social structures that result in hunger and poverty. While the first group (Ev.) lays great emphasis on spreading the gospel to "win souls for Christ", the second group (Ec.) is particularly concerned with aggressive social change and has a more passive attitude towards missionary work. The Ev. emphasise the Word - especially reading it according to the right doctrine (orthodoxy) - while the Ec., by comparison, holds the deed as more important (orthopraxis).

In summary, one could say that the Ev. group is worried that the individual believers and the church could begin to be of the world 
(be like the world), while the Ec. group is particularly concerned that the church should be present in (for) the world. The Ev. Christians therefore have the problem how the church - which may not be of the world - can still be in the world. The Ec. again have to take care that the church - which should be in the world - does not become of (identical to) the world.

\subsection{The danger of ecumenism and pluralism}

From the above it is, therefore, understandable that the two groups had difficulty in finding common theological grounds, and why Kato (cf. Breman, 1996a:146) typifies the Ec. as "leftist" and dangerous. $\mathrm{He}$ (Kato, 1975:183) formulates his own view very clearly:

Show concern in social action but bear in mind at all times that the primary goal of the church is the presentation of personal salvation. As individuals are converted, they become instruments of revolutionizing society for good.

The reason why this negative reaction by Kato is not unfounded, becomes evident from the critique by Antonides (1985) on the philosophy of the social gospel. However, the question is whether (as Kato states) individual conversion necessarily leads to social change.

The evangelical and ecumenical viewpoints also had distinct implications for the attitude of Christians towards their traditional religion and culture. The former adopted a more critical, antithetical attitude, while the latter was more inclined towards accommodation and synthesis. This was an additional reason for tension. Kato $(1975: 182)$ formulated his own view in this regard as follows:

Express Christianity in a truly African context, allowing it to judge the African culture and never the culture to take precedence over Christianity.

\subsection{The deeper roots}

We stated above that the Ev. and Ec. on the face of it hold radically different theologies. Van der Walt (1995:4), however, calls them estranged twin brothers, since they both try to ride the unbiblical see-saw of "in the world, but not of the world". The only difference is that the one puts more emphasis on "not of the world" (the transcendency/otherworldliness of the church), and the other on "in the world" (the relevance of the church). 
Within a dualistic theology (cf. 4.1 above), the Ev. stress the higher pole of grace (the church) and therefore evangelisation, while the Ec. shift the emphasis to the lower pole of nature (world) and consequently to social involvement.

In the end both views fall on their own swords, as a consequence of this unbiblical dualism. The Ev. Christians attempt to help the individual victims of a sinful social order - which they themselves often give their passive support! The Ec. Christians look for solutions to social evil in some or other form of secular philosophy (formerly, for instance, Marxism) - often the direct cause of the structural injustice! Both fall short of an integral Christian worldview, anthropology and analysis of society.

\subsection{A shift within the evangelical circle}

As a consequence of his antithetical attitude towards the world and traditional African beliefs, Kato was often called a "second Tertullian" (cf. Breman, 1996a:144; Bediako, 1992:386 ff.). The same name was suggested for Adeyemo at his funeral. Yet, the author surmises that Adeyemo's viewpoint was somewhat broader. Breman (1996a: 143) also states that after the well-known Lausanne 1 congress (1974) there was a change in the situation. So it is possible that Kato still held the Ev. viewpoint of before this important meeting, while Adeyemo was more in line with the Ev. view after Lausanne. Of what did this reversal consist? In short, the difference amounts to a worldview shift from an either-or view, to one of and-and.

During the early part of the previous century, before Lausanne 1, the former worldview was dominant. Evangelical Christians were advised to be against the world and its culture, and more or less isolate themselves from it. A truly reborn Christian, so it was believed, does not meddle in secular, worldly matters (like dirty politics). A personal devout life and spreading the gospel was the most urgent calling of every believer. In addition, Christians had to live morally correct - not to drink, fornicate, steal, swear, gossip or smoke. God's encompassing cultural mandate (Gen. 1:26-28) was not noticed and his command in Matthew 28:19, 20 was narrowed down to spreading the gospel.

Kinoti $(1994 b: 25,29)$ points out the influence of this world-fleeing view on African Christians as well. They should not dirty their hands with politics, but focus on spreading the gospel and do other "spiritual" work. 
At Lausanne 1 (1974) this dualistic point of departure was not rejected but only modified to an "and-and" view:

Although reconciliation with man is not reconciliation with God, nor is political liberation salvation, nevertheless we affirm that evangelism and socio-political involvement are both part of our Christian duty ... The salvation we claim should be transforming us in the totality of our personal and social responsibilities. (Quoted in Van der Walt, 1995:16.)

Adeyemo was clearly an advocate of this younger (post-Lausanne) view among the Evangelicals.

\section{Adeyemo as a representative of post-Lausanne evangelicalism}

Now first something on Adeyemo's work in general in the AEA and then an investigation into the evangelical worldview as the foundation of his theology.

\subsection{His work in the AEA}

Since the AEA already existed before Adeyemo's involvement in it, we first have to say something about his predecessor, Kato.

\subsubsection{B. Kato}

The AEA (originally AEAM) was established in the 1960s by Evangelicals from the West but made little headway. Kato was the first person who really breathed new life into it. Within two years (1973-1975) the national members (countries) for instance increased from seven to sixteen, representing approximately ten million Christians in Africa. Kato was an exceptionally gifted person and leader (cf. De la Haye, 1986 for his biography with a chronology on p. 114-118, as well as Breman, 1996a), but only two years after his appointment he drowned at the coast in Kenya. (For his viewpoints see inter alia the following publications: Kato, 1971; $1974 ; 1975 ; 1976$ and 1985.)

\subsubsection{Adeyemo's contribution}

During his long term (1977-2002) Adeyemo succeeded in uniting the evangelical Christians on the whole continent. (The national membership grew from sixteen to approximately 32, representing about 50 million Christians.) With his dynamic personality, vision, vigour and sense of vocation he expanded the AEA to a power house of 
evangelical thought and deed for the whole continent. Various departments were established within the AEA like the ones for society, ethics and development.

Through his mediation the Evangelical Theological School (in Bangui, Central African Republic) was erected for French-speaking Africans. In 1983 followed the Nairobi Evangelical Graduate School of Theology (NEGST) for English-speaking Africans in Kenya. Apart from these, care was taken to raise the standard of theological training by means of the Accrediting Council for Theological Education in Africa (ACTEA).

To this we should add the publication programme of the AEA which covered a wide spectrum like Bible studies, theological subjects, missionary work, African culture and worldview, socio-economic and political issues and leadership. (For particulars of the history of the AEA, cf. Breman, 1996b.)

Tokunboh's work was, however, not limited to Africa. He also was involved in the international evangelical world. Some examples are that he was honorary chairman of the World Evangelical Alliance (WEA), vice-chairman of the council of Open Doors International, member of the international council of Living Bible and the International Bible Society, Youth for Christ International and many more.

This brings us to the basic worldview message proclaimed by all these activities.

\subsection{Adeyemo's evangelical worldview}

We mentioned previously that the assembly of the Evangelicals in Lausanne (1974) brought about a shift in their worldview from an "either-or" to an "and-and" viewpoint (cf. Stott, 1975; Padilla \& Sugden, 1985).

\subsubsection{The evangelical line in Africa as well}

The same happened among the Evangelicals in Africa as well, among others in documents like "The Declaration of Nigerian Evangelicals" of 1975 (cf. De La Haye, 1986:119-126). It is a document which Adeyemo, as a Nigerian, would definitely have known. In this too the "and-and" view is put forward without removing the basic dualistic point of departure.

This is evident from the following: On the one hand this document says (De La Haye, 1986:121) that Christians should have a sound 
influence on political, economic and social life (Matt. 5:13), but later on there is a warning that Christians are indeed in the world, but may not be of the world (their true destiny is in heaven; De La Haye, 1986:120 - John 17:15-16). Christians' involvement in the world may not lead to bribery, corruption, nepotism, tribalism, an excessively luxurious life, et cetera. The individual believer should therefore also influence society by means of his changed life (De La Haye, 1986:123). Still later on it transpires (De La Haye, 1986:125) that social action includes taking care of the poor and pursuing justice.

However, right through the declaration the inherent tension between preaching the gospel and social involvement can be heard.

While social action is a Christian duty, it is not a substitute for evangelism which essentially is the proclamation of the good news for salvation of man from the penalty, power and, ultimately, the presence of $\sin$. (De La Haye, 1986:125.)

A few lines further: "Christians must not confuse the gospel with social action".

The stand taken in this document on traditional African culture and beliefs is also quite clear:

We believe that there are both good and bad elements in all cultures, including our own. As Christians we affirm that we must judge the elements of our own culture in the light of the Word of God. Things that are not in tune with biblical teaching such as immoral and pagan dancing, membership of secret societies and cults, ancestor worship, and other works of darkness we totally reject. (1 Pete 4:3; 1 Thessalonians 5:21, 22; De La Haye, 1986:124.)

From what follows now it will become clear that Adeyemo's viewpoint agrees with this Nigerian declaration of 1975.

\subsubsection{An ontological dualism}

In my opinion as ontological dualism is the major point of departure of Adeyemo's worldview, since it determines all of his theology. For this reason it is dealt with in detail.

It is noteworthy that Adeyemo often speaks (cf. Adeyemo, 1992:13) with approval of the holistic philosophy of traditional Africans, meaning the fact that they make no distinction between the profane and the sacred. Yet he (Adeyemo, 1990b:22) says that Christians have a 
double citizenship, for they are in but not of the world (John 17:11, 14). He clearly understands this well-known expression in a dualistic way, for on the very next page (p. 23) he says "there is a dichotomy between the sacred and the secular cosmos". Evidently there is no tension between these two spheres, for directly after this follow the words: "God rules over both and salvation is holistic." This view is the foundation for an article in which he deals with the attitude expected from Evangelicals towards socio-political affairs.

\section{- Implications}

The same line of thought recurs in the later work of Adeyemo (1997a:80). Firstly, he criticises politicians who create a sharp dichotomy between the secular and the sacred by contending that the state has to take care of the body and the church of the soul. On the very next page (Adeyemo, 1997a:81), however, it becomes evident that he does accept a two realm doctrine, but that God's authority over both has to ensure the unity between the two. "For all of life sacred and secular - is under God's authority..." (cf. also Adeyemo, 1997a:83). Therefore, to him it is no longer a question (as for the pre-Lausanne Evangelicals) whether Christians have to get involved in politics, but merely how it can take place (Adeyemo, 1997a:84). The question is whether, seen in the light of his basic dualism, he really could answer the how in a satisfactory manner.

\section{- Tension}

The question has to be put forward because no dualistic thinking can ever be without tension. In succeeding pages of the same document it clearly comes to the fore when he warns:

Avoid the danger of allowing political emphasis to overshadow the prime concern of the Church and the individual Christian, namely: personal redemption; inner communication with God; and a sense of the Kingdom of God. Never sacrifice devotion to God at the altar of service to God ... for the first and the greatest commandment remains: 'Love God with all your heart, soul and mind'. (Adeyemo, 1997b:98-99.)

On a subsequent page (Adeyemo, 1997b:111) more or less the same viewpoint is repeated and it is called a danger to the church: "Letting (the) political agenda overshadow the central concern of the church, which is redemption and a closer walk with God."

With reference to such statements the following questions could be raised: 
- Can a Christian's role in politics be overemphasised?

- Does politics have nothing to do with the kingdom of God?

- Is service not also devotion to Him?

- Is this not a case where the two parts of the fundamental commandment of love (towards God and the neighbour) are set against each other; while the Scriptures distinctly teach that through our love for our neighbour our love for God is revealed?

- With reference to the second quotation, one could further ask whether a person is inevitably nearer to God in the church and further from Him in politics.

- Does politics not also need redemption?

It is clear that Adeyemo could not conceal or overcome the inherent tension in his worldview dualism. In the end he chooses the sacred or the pole of grace over the secular or pole of nature in this dualism.

Therefore he does not choose for a Lutheran worldview according to which church and state are to exist next to each other, nor for the identification of the two. Instead, he chooses the Roman-Catholic view according to which the church is above the state (Adeyemo, 1997b:100). This raises the obvious question of how a Christian (who should stand above politics) could still have any influence in politics.

\section{- Incorrectly based on the Scriptures}

Since one's own worldview determines your exegesis of the Scriptures, Adeyemo is of the opinion that his viewpoint is prescribed by God Himself: "God has placed distinction between the spheres of operation - Church, sacred; state, secular" (Adeyemo, 1997b:108). Thus he succeeds in reading his dualistic view into the Scriptures, for example in the well-known Matthew 22:21 "Give to Caesar what is Caesar's, and to God what is God's".

According to Adeyemo (1997b:102) this text means that Christ distinguishes between secular and sacred, the material and the mystic. Simultaneously he attempts to avert the inherent tension between the two spheres by rejecting the Lutheran view (of secular and sacred next to each other) and then resuming:

By approving both options by the word 'give' Jesus ruled out a dualism of two parallel rails that never meet. While the acts of 
giving are directed at two distinct realms, the giving itself springs from the same source. Therefore, this paradigm illustrates how a believer who enjoys dual citizenship, heaven and earth, should relate to church and state. (Adeyemo, 1997b:102103.)

\subsubsection{A dichotomist anthropology}

The most profound reason why a human being has double "citizenship" (cf. also previous quotations) is that he is, according to Adeyemo, a dichotomous being - in other words he consists of two parts. A dualistic ontology or worldview mostly leads to a dichotomist anthropology.

\section{- The human being as soul and body}

He does not deal directly with his view of the human being, but the following statement reveals this age-old dichotomist anthropology: "[The] Church may be rated higher in God's hierarchy of things in as much as the Spirit is more important than the body but not in a dualistic sense." (Adeyemo, 1997b:109.) In my opinion the final words of the sentence ("not in a dualistic sense") is contradictory to the preceding part. Unity of soul and body still presupposes the unity of two separate components. (In Adeyemo, 1993b:v he even advocates a trichotomy of body, soul and spirit on the grounds of 1 Thess. 5:23.)

\section{- An unbiblical idea}

Such an anthropology cannot be justified on the basis of the Scriptures. It can, however, as it used to be the case for centuries, be read into the Bible - and it influences (as is clear above) the way one sees your vocation and duty in society. The church and "spiritual" matters usually are more serious than "ordinary" matters, missionary work (winning immortal souls) more important than any cultural activity. The emphasis on the immortal (divine) "part" of a human being means that his actual destiny is heaven and that the terrestrial, bodily "part" is not really that important.

\subsubsection{General and specific revelation}

A dualistic ontology and anthropology usually leads to a dualistic view of God's one but threefold revelation. 


\section{- God's creational revelation underrated}

Adeyemo pays almost no attention to God's creational revelation (a better designation than "general" revelation). He does bring it into his doctoral thesis to show that the traditional African religions did know about God as Creator, but not as Saviour (cf. Adeyemo, 1978:3 \& 205). God's special revelation (a better designation would be God's revelation in the Scriptures) is, therefore, much more important, since his "general" revelation exhibits various limitations (cf. Adeyemo, 1978:203; and also his predecessor Kato, 1971).

\section{- Overemphasis on the Scriptures leads to biblicism}

Adeyemo does not do justice to the unity of God's threefold revelation (in creation, Scripture and Christ - each one with its own purpose/focus). His dualistic ontology (of matter and spirit) likewise leads to a dualistic view of revelation. In this all the emphasis is laid on God's revelation in the Scriptures.

Even with the best of intentions this necessarily leads to biblicism. Adeyemo's biblicist worldview need not be proved here, as it transpires from all his writings. Whatever the subject, he tries to approach it only from the Bible.

The reformational tradition, however, differentiates between God's original creational revelation, the "republication" thereof in his Word written down; and his revelation incarnate in Christ. Through the study of God's creational revelation (e.g. the regular functioning of all created things) much can for instance be inferred about God's creational order. The Scriptures teach us about creation, its fall and redemption and in Christ we have God's final revelation of how one should live. God's creational revelation should be studied in the light of his revelation in the Scriptures and his revelation in Christ.

\section{- Expecting too much or too little from the Scriptures}

One can expect too little from the Bible by regarding it as only relevant to "spiritual" matters. One can, however, also expect or ask too much from the Scriptures by seeking its light for any problem you encounter. In my opinion Adeyemo on the one hand, expects too little by not succeeding in really pointing out what the biblical light is on social, political and economic matters. On the other hand, he expects too much when, for instance, he attempts to infer mainly from the examples of Bible characters everything on better leadership for today (a completely different environment from the biblical one) (cf. Adeyemo, 1993a; 2009). 
Although evangelical - and also reformed - people do not realise this, they are making an idol out of the Bible by asking too much from it. An equally great threat is that the Word Incarnate (Christ) in this way is "murdered", for it is not the Bible but Jesus Christ (of whom the Scriptures do tell us) who is God's absolutely final, and therefore most authoritative, revelation.

Devaluating any one form of God's threefold revelation undermines the two other forms. To ignore or minimise any part of God's revelation moreover distorts one's relationship to God himself, and therefore also one's understanding of his world and our calling in the many facets of society.

It is noteworthy that Adeyemo pays little attention to distinct normative guidelines for the different spheres of life. Could it be that his dualistic idea of revelation also implies a double natural and a supernatural normativity?

\subsubsection{Church and kingdom}

Normally a dualistic view leads to the simple distinction of merely "church and world" - as if the church is not a part of this world and the world does not consist of a much greater diversity of societal relationships than only the church and the state. In addition, it mostly leads to an identification of church and kingdom.

In the work of Adeyemo (1997b:105) this also happens: "Although God's direct rule or kingdom is limited to his Church today, it shall extend to the whole society when Christ returns" (Rev. 19). This links up with his negative statement (cf. Adeyemo, 1997b:55) on Abraham Kuyper's well-known distinction between the church as an organism (the kingdom), and the church as an institution. According to Adeyemo the Bible never speaks separately of the church as an institution.

However, this statement can be queried. Of course the Scriptures do not use technical terms, but nevertheless a clear distinction is made between the (e.g. local) church and the encompassing kingdom of God, which means God's reign, not only over the church but over the whole of creation - including all societal relationships.

\subsubsection{Evangelisation and social involvement}

In Adeyemo's worldview the original cultural mandate (of Gen. 1:2628) does not play an important role. All emphasis falls on the "mission command" of Christ (of Matt. 28:19), which in reality is simply a 
new version of the cultural mandate in the light of Christ's redemption. But since he more or less identifies church and kingdom the church should also be involved in society.

We will be looking at:

- the lack of clarity regarding the concepts evangelisation and social involvement;

- Adeyemo's motivation for the social involvement of the church;

- the difficult balance between these two; as well as

- the way in which the church should change society.

\section{- What is meant by these concepts}

One cannot find clarity from Adeyemo's writings on what the actual difference is between evangelisation and social involvement.

The biblical concept of spreading the gospel, in my opinion, includes many things which evangelical Christians would call social involvement. Examples are - apart from leading individuals to conversion, preaching the good news to prisoners and the poor, and calling upon the nations to obey God's commands. Conversion actually means going over from an old way of life into a new one in every facet of our human existence.

Social action cannot be limited to helping people in need either. Singing, making music and painting, for instance, are not social actions nor evangelisation. Yet God commands us to do these too and do them properly. The same applies to playing, dancing, writing poetry, trading, dressmaking, cultivating vegetables, building houses, raising children and so forth - these are all part of our cultural duty.

These two concepts (evangelisation and social action) are therefore not only very vague, but also far too restricted to denote the Christian's vocation in God's kingdom. (In terms of this false dichotomy, one may say that true Christian evangelisation always includes social involvement and true Christian social action is always evangelising by nature.)

Adeyemo's motivation for the church's involvement in the world is already known. He says for instance (Adeyemo, 1997b:58): "Much as she [the Church] has been called to worship the Lord, she has also been sent to serve the world (John 17:18; 20:21)". Once again 
the question can be raised whether worshipping and serving God are two totally different matters. Is it not accurate to say that worshipping God also becomes evident in serving Him obediently?

\section{- The balance}

The precarious balance to be maintained between the two tasks of the church, transpires from the following words of Adyemo (1997b: 112): "The church is to be in contact with the world, but at the same time it must maintain and preserve its purity; a contact without contamination." The background to such a statement is obviously the dualism of a church seen as holy (show me a sinless church) against the rest of the world seen as sinful by nature.

\section{- The way it should be}

The way the church should be involved in society is also problematic as I see it. According to Adeyemo (1997b:114) it is done exclusively by individual members of the church. The meaning of being salt and light (Matt. 5:13-16) is narrowed down to an individualistic way of personal obedience to God's commandments, the fruit of the Spirit, a positive attitude, Christian virtues, a prophetic role, and giving one's children a good upbringing.

One has to agree with Adeyemo that true change should begin at a personal level with heart-felt conversion. It also is true that the example and witness of individual persons can be of great value. The heart of reformation is the reformation of the heart. This is the right beginning, but unfortunately it may not end here. The mighty, growing secular culture (in Africa too, cf. Shorter \& Onyancha, 1997) which surrounds Christians on all sides cannot be opposed by individuals only. It requires the joint, organised action of Christians. After his thorough investigation into the enormous growth of especially the charismatic pentecostal churches in Africa (cf. 3.1 above), the conclusion made by Gifford (1998:348) is that any transformation of Africa's catastrophic decay by the examplary lives of individual Christians only, would be sorely limited. He furthermore contends that this kind of church cannot have much influence on the social, political and economic situation of the continent. This conclusion is confirmed by an African (Kinoti, 1994a:1).

In contrast to this typical evangelic way of attempting to change society, we have the reformational approach, which is to attempt transformation in the broader community by means of Christian organisations and institutions in various spheres. Adeyemo is aware 
of such a strategy in different countries, but it is not acceptable to him. His reason is the endemic ethnic problems and religious fanaticism in Africa (cf. Adeyemo, 1997b:98).

\section{- An alternative}

In my view such an argument against organised Christian action does not hold water. His problem is that he - like most Evangelicals - does not have a Christian philosophy of society. Such a social view consists of mainly two components: structural diversity and confessional diversity (for detail, cf. Van der Walt, 2010). The former principle not only accepts the church and state, but a variety of societal relationships. The latter kind of pluralism teaches that religious convictions are also entitled to being practised in the public sphere in various organisations (like political parties) and institutions (like Christian, Muslim and secular schools).

In opposition to Adeyemo's fear that such religiously-oriented organisations and institutions may cause tension and even violence (as today in his land of birth, Nigeria, between Christians and Muslims), Boer (2003:16 ff.) argues in favour of confessional pluralism. According to him it is precisely because Christians and Muslims (and all other religions) are not given equal opportunity to also practise their religious convictions in public spheres (while it can never really be suppressed) that tension and violence ensue.

\section{- Christian organisations and institutions as a solution}

Antonides (1985:222-223) gives the following motivation for Christian organisations and institutions: It is the logical outcome of the faith of reformational Christians that God is sovereign and should be served in all spheres of life. Secondly, it also implies that no organisation/institution can be religiously neutral. Furthermore the grace of God is not restricted to the church. Fourthly, Christian organisations bring the communal character of their Christian faith to the fore. In addition, Christian organisations through their involvement in nonclerical spheres, offer opportunities for Christians from different denominations to cooperate across the borders of churches (while they are often inclined to absolutise their own church and to ignore others). Sixthly, Christian organisations help to build a pluralistic society in which the rights of different religions are acknowledged and respected. Moreover, Christian actions cause God's multicoloured law of love to take form in different spheres of life. This central commandment of love should not be applied in an undifferentiated way, but in various ways in different cultural contexts. Love 
takes the form, for example, of mutual fidelity in marriage, brotherly love in the church, and justice in the political sphere.

The most serious motivation for Christian organisations and social action, however, is that it is the only truly effective method of bringing about social change. Antonides (1985:223) explains:

When Christians believe that the church or church-related agencies are the exclusive channels of Christian action in society, Christian action is restricted, and the non-ecclesiastical areas of life become further estranged from the Gospel. The witness the church then brings to areas of life such as politics or economics simply amounts to an admonition from the outside without any effective, inner reformation. Christian organizations are intended to bring about reformation from the inside of political life, economic life, and so on. The difference is not merely a matter of strategy, but involves a fundamentally different way of viewing the world and the meaning of God's Word for our lives.

We now look at the last aspect of Adeyemo's way of thinking.

\subsubsection{Christian faith and traditional African religion, spirituality and culture}

In this respect Adeyemo holds a firmly antithetical viewpoint, while he also retains appreciation for certain elements of the African worldview and culture.

\section{- Redemption only in Christ}

In Adeyemo's work (1979a; 1997a - his original M.Div. thesis, as well as 2006b; 2006c) he states very clearly the differences between the traditional African religions and the biblical ideas of redemption.

Salvation in the thought of the traditional African peoples ... implies acceptance in the community of the living and of the livingdead, deliverance from the power of the evil/spirits and a possession of life force. (Adeyemo, 1997a:94.)

In contrast to this he (Adeyemo, 1997a:96) quotes well-known texts like John 14:6 and Acts 4:12, which name Christ as the only Way of salvation. It was mentioned above that he is of the opinion that the traditional African did know God as Creator from his creational revelation, but not yet as a Saviour. He therefore is in favour (cf. Adeyemo, 1978:3) of letting the traditional belief (in a Creator-God) serve as a "point of contact" for preaching salvation in Christ, but at the same time he (Adeyemo, 1997a:1) is against a kind of "univer- 
salism" found among African theologians (like Idowu and Mbiti), who see merely a difference of degree and not an essential difference between traditional African religions and Christianity.

\section{- Christianity and African culture}

Regarding African culture in particular, his viewpoint is clear too. In order to preach the gospel in an effective way, knowing the specific culture is essential, but "in the process, the uniqueness of biblical revelation should be maintained, and where culture and God's word conflict, the former must give way" (Adeyemo, 1978:211).

Adeyemo $(2009: 18,19)$ was also outspoken on certain elements of his traditional culture that are unacceptable causes of the dire situation in which the continent finds itself. Among others he mentions the following:

- The supernatural explanations given to events prevent the acceptance of personal responsibility.

- The enormous emphasis on tribal relations leads to nepotism and other kinds of corruption.

- The accent placed on the past foils planning for the future.

- Younger people are excluded form leading positions.

- People are allowed to cling to political positions and other kinds of power for a lifetime, thus making democratic government impossible. Adeyemo reduces the many problems in Africa mainly to a crisis in leadership. (Osei-Mensah, 1989 \& 1990; Zokoue, 1990; and Turaki, 1997:14 agree with him on this.)

In contrast to his critique, there is the fact that he nevertheless appreciate some traits in traditional African culture, and even regards them as possible valuable contributions to Christianity (cf. Adeyemo, 1994b). Materially-spoken Africa is poor, but they can enrich the West spiritually (2 Cor. 6:10 is quoted here). Among these elements are Africa's inherent religiosity; the fact that Africans are centred on human beings (in contrast to Western individualism); their adaptability; their holistic approach to life (instead of Western dualism), respect for nature, and emphasis on history (the past). But in my opinion all these traits can have both positive and negative implications. 


\section{- African spirituality}

Moreover it can be asked whether this type of "spirituality" that Adeyemo advocates is actually realised in the practice of African Christianity or whether it is perhaps imported from the West. For instance, he makes very positive statements (cf. Adeyemo, 1994b:11,12 ) about Pentecostalism and the charismatic churches, which, according to him, are growing the most rapidly in Africa and says: "A substantial contribution is being made to Christendom by this Movement." (Earlier it is mentioned that Adeyemo was a member and elder of a pentecostal church in Nairobi.)

However, the author's personal experience with this type of spirituality in Africa is all but positive (cf. Van der Walt, 2008:503-507 for a characterisation of it). Among other things it is very emotional, dualistic and escapist. In opposition to this, Fowler (1995:153) states that true spirituality according to the Scriptures, denotes the central driving force of one's life as a whole:

The person who lives as a renewed person by the Spirit of Christ is a person called to live a life that is guided and directed by the Spirit in all things; the spiritual person is one who presents his/her whole bodily life in this world as a living sacrifice to God - Romans 12:1-3; Galatians 5:25.

\subsection{Summary evaluation}

After the critical remarks on the above exposition of Adeyemo's evangelical worldview, we now summarise it here.

\subsubsection{The unsolved problem of evangelical thinking}

The fundamental dualistic point of departure of the Evangelicals leads to their viewing everything through double focus glasses. As long as these worldview glasses are not replaced by a truly holistic, integral, biblical worldview, their theology will not be able to change either.

This is evident from the developments after Lausanne 1 (1974). At that time the and-and viewpoint was adopted instead of the earlier either-or view (either the church or the world). But in doing this the inherent dualism itself was not rejected. The relationship between the two poles of their dualism was only seen in a different way. Afterwards mainly three viewpoints took shape as time went by:

- social involvement is the result of evangelisation; 
- it can form a bridge to spreading the gospel; or

- it can accompany preaching the gospel.

The problem with the first option, however, is that social involvement is not a necessary or logical consequence of spreading the gospel. Ministers can preach openly on social involvement without the church members doing anything about it. The bridge idea is nothing new either and not without hazards. Schools, clinics, charity work, development projects and so forth could easily be used to lure people to accept the gospel. Such actions then become mere instruments for evangelisation and will not be independent vocations (spheres) in God's kingdom. Even in the idea of a partnership, preaching the gospel and social involvement remain two separate matters. The fundamental dualism still has not been addressed. This in spite of the beautifully formulated Manilla Manifesto ("The Gospel and social responsibility") in which the whole church is called up to preach the full gospel to the whole world.

\subsubsection{The great void}

It is noteworthy that the lack of an encompassing, integral Christian worldview for Africa was actually discerned in the AEA by Adeyemo himself. In a volume of which he was the editor and for which he wrote the preface (cf. Adeyemo, 1993b) the following recommendations are made inter alia:

We are convinced that an integrated ['integral' would have been a better word] Christian worldview based upon the Holy Scriptures, the Bible [why only the Bible?], is an indispensable foundation to live out an authentic Christian life in contemporary society, hence the imperative of calling on all Christians to develop a Christian worldview within the African context. The battle, therefore, is for the Christian mind to think Christianly and to grasp the full implications of the Lordship of Christ over all areas of life. This implies the necessity to develop a Christian anthropology and Christian social philosophy. (Adeyemo, 1993b:227.)

Unfortunately we have to state that the ideal of an integral Christian reformational worldview with a truly Scripture-based anthropology and philosophy of society, was not realised by either the AEA or Adeyemo himself. They could not escape the tremendous power of an age-old dualistic Christian worldview. 


\subsubsection{The alternative}

As an alternative we now only briefly give some outstanding traits of a reformational worldview.

\section{- No dualism between creation and redemption}

The created earth is important. In Christ, God says "Yes" to his creation (cf. 2 Cor. 1:19, 20). It also is the home of human beings at present and after the resurrection. It is on this (new) earth that God wants to establish his kingdom and will do so. A dualism between creation and re-creation, therefore, is unacceptable. According to such dualisms the biblical concept of a religious antithesis, of a spiritual battle between two opposite directions in life after the fall, is incorrectly turned into a structural or ontic dichotomy. Certain parts, domains, spheres (e.g. the church or theology) are regarded as holy (and of course Christian), while others (e.g. politics or the academia) are seen as secular or neutral.

The Word of God rejects such dualisms. There should be no tension between love of and service to God, and service in this world. As an earthly being one cannot but serve God in this world. Therefore the commandment of love forms a unity: by loving my neighbour I also fulfil my love of God (cf. 1 John 4:20, 21). Thus, the nearer one lives (according to God's commandments) to his creation, the nearer one lives to God; and the nearer to God, the more concerned one will be about his creation. This can also be applied in a negative way: the further one is from God, the further from his creation; or: the less one cares about his creation, the further one lives from the God whose creation it is.

\section{- The cultural mandate as an encompassing mandate}

We read in Genesis 1:28 and 2:15 that humanity received an encompassing cultural mandate to take care of the whole creation and to develop it further. In Matthew 28:18-20 Christ does not give a separate, new missionary assignment - the way some evangelical Christians believe - that is more important than the original cultural mandate. Since all power in heaven and on earth has now been given to Him (Matt 28:18), this all-encompassing duty of claiming creation for Him can only now really be fulfilled by his disciples guided by the Holy Spirit. 


\section{- A religious antithesis}

The foregoing point already presupposes the fall, which does not mean a lack of what is good, but a fundamental change in direction and a deeply religious antithesis. Satan and his followers are against God's creational order, while believing Christians want to obey it.

However, this antithesis cannot always be clearly localised (e.g. by thinking that the church is good as a matter of course and politics is automatically bad). Since the antithesis cuts right through every person's heart, even Christian organisations and institutions are not perfect and they may therefore never be equated to God's perfect kingdom. The opposite also holds: because of God's grace over all people there are also good things to be found in non-Christians.

\section{- Structure and direction}

A reformational worldview sees no dualistic tension between God's grace and his creation (nature). God's redeeming grace does not stand in opposition to his creation so that He has to destroy creation in order to free it from the power of evil. Neither is his grace a mere addition to creation so that it does not mean any real change. His grace entails the renewal of creation so that it will once more comply with his creational order. (The opposite of "grace" is not "nature" but the wrath of God.)

To explain this, reformational thinkers use the distinction between structure and direction. Structure denotes the created cosmos according to God's order, which is still valid in spite of the fall. Direction denotes the wrong religious direction (disobedience to God's creational order and his central commandment of love) after the fall. But it can also denote a corrected direction of obedience through the grace of Christ and guided by the Holy Spirit.

This distinction is significant, as it prevents us from dividing (as the Evangelicals do) creation according to an unbiblical two realm doctrine into natural and supernatural spheres. However, it also has its limitations. Structure and direction may not be separated in a watertight manner. An incorrect direction of disobedience (infidelity) in a marriage can structurally destroy the marriage. Unless the norm of impartial justice in the political sphere is obeyed, it has distinct structural consequences. The opposite is also true: a degenerate structure (e.g. a marriage on the rocks) cannot easily be brought back to the right direction (of mutual fidelity). 


\section{- Fundamental, encompassing religion}

From the foregoing it should already be clear that a human being's religious direction (in obedience or in disobedience to God's structural laws and fundamental commandment of love) is fundamental and all-inclusive. It is also not limited to, for instance, personal faith and cultic practices. Nothing that a human being does, can therefore be "neutral" in the religious sense.

\section{A final appreciation}

Like any other thinker, Adeyemo also was a child of his times. Every human being stands on the shoulders of his predecessors in a specific tradition. From the foregoing critical discussion of the evangelical tradition it transpired that a truely reformational worldview tradition can offer a deeper and broader worldview. But this does not mean that we deny the contribution of this great son of Africa. We therefore finally set it out point by point below.

- There is no doubt that he was a deeply religious and devout person. The very example of his life as a Christian had an enormous influence on numerous other people - on the author too.

- He loved God with all his heart, held onto his Word and explained it - also to ordinary people.

- He had a passion for spreading the gospel worldwide.

- Adeyemo also realised that the gospel could not be preached effectively to the people of Africa without an understanding of their traditional culture and religion.

- The great emphasis he placed on the authority of God's Word, prevented him from - what most African theologians did - favouring mere accommodation (synthesis and even syncretism) between the gospel and traditional African religions and cultures. He held a balanced view, namely that certain traditional customs are unacceptable in the light of the Scriptures, but that others should be retained as characteristics of a typical African Christianity.

- Adeyemo's view of the constellation of political, social and economic circumstances in Africa was also honest and balanced. For instance, he did not - as is still happening in Africa - lay all the blame for the pitiful conditions on the continent on Western colonialism in the past. He admits that -50 years after independence - Africans themselves have to take responsibility and he also points out where the main problems are. This he does without 
lapsing into Afro-pessimism. Until the end of his life he gave his knowledge to train better leaders for the continent by means of his Center for Biblical Transformation.

- By his organisational talent and involvement over the course of many years he also united millions of Christians in the AEA, and opened their eyes to the fact that as Christians they have a calling and a duty in the world.

- With the pen, too (his numerous writings) he exerted a wide influence.

- To him education was not unimportant. He considered it essential in the development of leaders for the continent.

- While people outside Africa were mostly uniformed about the real state of Christianity on the continent, he regularly kept them abreast of both its strengths and weaknesses.

There is an African proverb that says one should not attempt to embrace a giant baobab tree with one's arms. This is particularly relevant when one attempts to describe and evaluate the life of someone like Tukunboh Adeyemo. Nevertheless, the author trusts that this article will afford a glimpse of the life and work of this African giant whom we have lost.

\section{Lists of references}

\section{Works by T. Adeyemo}

This bibliography is not complete (for instance, it does not include Adeyemo's articles in the popular newsletter, Afroscope, the official publication of the AEA.). However, it does contain Adeyemo's most important publications. Since the author has no knowledge of a similar, fairly representative bibliography (except for Breman, 1996b:594-551), this one can be seen as a beginning for the research in this article and as a basis for a later more inclusive bibliography. (Publications, to which no reference is made in the text above, are therefore also included.)

ADEYEMO, T. 1976a. The doctrine of salvation in African Traditional Religion. La Mirada: Talbot Theological Seminary. (M.Div.Thesis.) ${ }^{2}$

2 This dissertation forms the basis of his book Salvation in African tradition (Adeyemo, 1979a \& 1997a). 
ADEYEMO, T. 1976b. A theological critique of church indigenization in Africa. La Mirada: Talbot Theological Seminary. (Th.M. thesis.)

ADEYEMO, T. 1978. The doctrine of God in African traditional religion. Dallas: Dallas Theological Seminary. (Doctor of Theology Thesis.)

ADEYEMO, T. 1979a. Salvation in African tradition. Nairobi: Evangel Publishing House. (New edition, cf. 1997a.)

ADEYEMO, T. 1979b. African traditional religion, Christianity and Islam: a socio-theological enquiry of continuity and discontinuity in conversion. Aberdeen: University of Aberdeen. (Ph.D. thesis.)

ADEYEMO, T. 1984-1993: Approximately 30 editorial and other articles in the journal Transformation: an international journal of holistic mission studies. (Available without charge on the Internet.)

ADEYEMO, T. 1984a. The church in Africa today. Orientation: international circular of the PU for CHE, 32:22-36, Mar.

ADEYEMO, T. 1984b. The social responsibility of the church. Orientation: international circular of the PU for CHE, 33:74-93, Jun.

ADEYEMO, T. 1984c. The gospel in African context. Orientation: international circular of the PU for CHE, 35:50-58, Dec.

ADEYEMO, T. 1984d. Church in Africa today and tomorrow. Nairobi: Evangel Publishing House.

ADEYEMO, T. 1985a. The church in Africa during the next five years. Orientation: international circular of the PU for CHE, 39:1-16, Dec.

ADEYEMO, T. 1985b. The task of nation building. Orientation: international circular of the PU for CHE, 39:57-65, Dec.

ADEYEMO, T. 1986. Christ's ambassadors in an Islamic context. Potchefstroom: Institute for Reformational Studies. (Study pamphlet no. 224.)

ADEYEMO, T. 1988. Following Jesus in Africa today. Nairobi: AEAM.

ADEYEMO, T. 1990a. The church in Africa today. (In Okoronkwo, G., ed. Church and society ... can they work in harmony? Nairobi: Association of Evangelicals in Africa. p. 9-21.)

ADEYEMO, T. 1990b. Where the Evangelicals stand in socio-political issues. (In Okoronkwo, G., ed. Church and society ... can they work in harmony? Nairobi: Association of Evangelicals in Africa. p. 22-29.)

ADEYEMO, T. 1991a. Law and grace. (In Okoronkwo, G., ed. Social ethics in African Christian theology. Nairobi: Association of Evangelicals in Africa. p. 42-46.)

ADEYEMO, T. 1991b. The church as an agent of change in Africa. Nairobi: AEAM.

ADEYEMO, T. 1992. Africa at a crossroad. Nairobi: Association of Evangelicals in Africa.

ADEYEMO, T. 1993a. The making of a servant leader. Nairobi: Christian Learning Materials Centre.

ADEYEMO, T., ed. 1993b. A Christian mind in a changing Africa. Nairobi: Association of Evangelicals in Africa.

ADEYEMO, T. 1993c. African worldview and its socio-economic and political implications. (In Adeyemo, T., ed. A Christian mind in a changing Africa. Nairobi: Association of Evangelicals in Africa. p. 7-23.)

ADEYEMO, T. 1994a. Beyond Africa: the African Church's global involvement in missions. Nairobi: Association of Evangelicals in Africa. 
ADEYEMO, T. 1994b. African contribution to Christendom. Nairobi: Association of Evangelicals in Africa.

ADEYEMO, T. 1995. Reflections on the state of Christianity in Africa. Potchefstroom: Institute for Reformational Studies. (Study pamphlet no. 332.)

ADEYEMO, T. 1997a. Salvation in African tradition. Nairobi: Evangel Publishing House. (Revised ed. of 1979a.)

ADEYEMO, T. 1997b. Is Africa cursed? Nairobi: Christian Learning Materials Centre.

ADEYEMO, T., ed. 2006a. Africa Bible commentary: a one-volume commentary written by 70 African scholars. Nairobi: WordAlive Publishers.

ADEYEMO, T. 2006b. Ideas of salvation in other religions. (In Adeyemo, T., ed. Africa Bible Commentary. Nairobi: WordAlive Publishers. p. 1353.)

ADEYEMO, T. 2006c. Religious pluralism. (In Adeyemo, T., ed. Africa Bible Commentary. Nairobi: WordAlive Publishers. p. 1532.)

ADEYEMO, T. 2006d. Leadership. (In Adeyemo, T., ed. Africa Bible Commentary. Nairobi: WordAlive Publishers. p. 546.)

ADEYEMO, T. 2009. Africa's enigma and leadership solutions. Nairobi: WordAlive Publishers.

ADEYEMO, T. \& AYEE, E., eds. 1989a. Following Jesus in a plurasistic society. Nairobi: AEAM.

ADEYEMO, T. \& AYEE, E., eds. 1989b. Following Jesus in a segregational society. Nairobi: AEAM.

ADEYEMO, T., OKORONKWO, G. \& AYEE, E., eds. 1988. Following Jesus in a rich-poor society. Nairobi: AEAM.

\section{Other sources consulted}

ADEYEMO, I. 2010. Eulogy (at her husband's funeral on 26 March 2010 in the AEAM church at Ibadan, Nigeria) (Unpublished.)

see ASSOCIATION OF EVANGELICALS IN AFRICA AND MADAGASCAR

ANON. 2008. Faith on the move: Pentecostalism and its potential contribution to development. Parktown: Center for Development Studies.

ANTONIDES, H. 1985. Stones for bread: the social gospel and its contemporary legacy. Jordan Station: Paideia.

ASSOCIATION OF EVANGELICALS IN AFRICA AND MADAGASCAR. 1984. Church in Africa today and tomorrow. Proceedings of AEAM 4th General Assembly, Malawi. Nairobi: Evangel Publishing House.

BEDIAKO, K. 1992. Theology and identity: the impact of culture upon Christian thought in the second century and in modern Africa. Oxford: Regnum Books.

BOER, J.H. 2003. Nigeria's decade of blood. Belleville: Essence Publications. (Studies in Christian-Muslim relations, vol. 1).

BREMAN, C.M. 1996a. Portrait of dr. Byang Kato. African journal of evangelical theology, 15(2):135-151.

BREMAN, C.M. 1996b. The Association of Evangelicals in Africa: its history, organization, members, projects, external relations and message. Zoetermeer: Uitgeverij Boekencentrum. 
COLE, V.B. 2010. Eulogy (at the funeral service on 23 March 2010 in Nairobi Pentecostal Church, Nairobi for dr. T. Adeyemo). (Unpublished.)

DE LA HAYE, S. 1986. Byang Kato: ambassador for Christ - biography of dr. Byang H. Kato. Achimota: Africa Christian Press.

FOWLER, S. 1995. The oppression and liberation of modern Africa: examining the powers that shape today's Africa. Potchefstroom: Institute for Reformational Studies.

GIFFORD, P. 1998. African Christianity: its public role. London: Hurst.

GIFFORD, P. 2004. Ghana's new Christianity: Pentecostalism in a globalizing African economy. London: Hurst.

HAYES, S. 1998. African Initiated Church theology. (In Maimela, S. \& König, A., eds. Initiation into theology. Pretoria: Van Schaik. p. 159-178.)

HELLEMAN, A.A. \& AHIMA, C. 2004. Let justice roll down like waters: a study on biblical justice for Africans. Jos: Stream Christian Publishers.

JENKINS, P. 2002. The next Christendom: the coming of global Christianity. Oxford: Oxford University Press.

JENKINS, P. 2006. The new faces of Christianity. Oxford: Oxford University Press.

KATO, B.H. 1971. Limitations of natural revelation. Dallas: Dallas Theological Seminary. (Master's thesis.)

KATO, B.H. 1974. A critique of incipient universality in Tropical Africa. Dallas: Dallas Theological Seminary. (Doctoral dissertation.)

KATO, B.H. 1975. Theological pitfalls in Africa. Nairobi: Evangel Publishing House.

KATO, B.H. 1976. Creating facilities for Evangelical theological training in Africa. (In Bingle, H.J.J. et al. Christian Higher Education: the contemporary challenge. Proceedings of the First International Conference of Reformed Institutions for Christian Scholarship, 9-13 Sept. 1975. Potchefstroom: Institute for the Advancement of Calvinism. p. 360-364.)

KATO, B.H. 1985. Biblical Christianity in Africa: a collection of papers and addresses. Achimoto: Africa Christian Press.

KINOTI, G. 1994a. Hope for Africa and what the Christian can do. Nairobi: AISRED.

KINOTI, G. 1994b. African Christian and the future of Africa. Transformation, 11(3):24-32.

KLEIN, W. 1998. Evangelical hermeneutics. (In Maimela, S., König, A., eds. Initiation into theology: the rich variety of theology and hermeneutics. Pretoria: Van Schaik. p. 319-336.)

KÖNIG, A. 1998. Evangelical theology. (In Maimela, S., Künig, A., eds. Initiation into theology: the rich variety of theology and hermeneutics. Pretoria: Van Schaik. p. 81-110.)

MÖLLER, F. 1998. Pentecostal theology. (In Maimela, S. \& König, A., eds. Initiation into theology. Petoria: Van Schaik. p. 179-190.)

MONSMA, T. 2006. Hope for the southern world: impacting social problems in the non-Western world. Lovedale: CCW Books.

ODEN, T.C. 2007. How Africa shaped the Christian mind: rediscovering the African seedbed. Downers Grove: InterVarsity Books.

OSEI-MENSAH, G. 1989. The challenge of Christian leadership in Africa today. East African journal of evangelical theology, 8(2):4-10.

OSEI-MENSAH, G. 1990. Wanted: servant-leaders - the challenge of Christian leadership in Africa today. Achimota: Africa Christian Press. 
OVERDULVE, C.M. 1994. Rwanda: volk met een geschiedenis. Kampen: Kok.

PADILLA, R. \& SUGDEN, C., eds. 1985. Texts on evangelical social ethics. Bramcote: Grove Publishers.

PARRATT, J. 1995. Reinventing Christianity: African theology today. Grand Rapids: Eerdmans.

PEARCEY, N. 2004. Total truth. Wheaton: Crossway Books.

SCHREITER, R.J., ed. 1992. Faces of Jesus in Africa. London: SCM.

SHORTER, A. \& ONYANCHA, E. 1997. Secularism in Africa: a case study Nairobi City. Nairobi: Paulines Publishing Africa.

STOTT, J.R. 1975. Explaining the Lausanne Covenant. London: Scripture Union.

THERON, J. 1998. Charismatic theology. (In Maimela, S. \& König, A., eds. Initiation into theology. Petoria: Van Schaik. p. 191-202.)

TURAKI, Y. 1997. The tribal gods of Africa: ethnicity, racism, tribalism and the gospel of Christ. Jos: Crossroads Media Services.

VAN DER WALT, B.J. 1983. Visie, werklikheid, visioen: flitsindrukke van die IRS-konferensie van 4 \& 5 November 1983 oor "Die betekenis van die Reformatoriese lewensvisie vir Afrika". Potchefstroom: Instituut vir Reformatoriese Studie.

VAN DER WALT, B.J. 1994. Voorlegging vir die toekenning van die graad Th.D. (Honoris Causa) aan dr. Tokunboh Adeyemo, Alglemene Sekretaris van die Association of Evangelicals in Africa, Nairobi, Kenia, op 17 Mei 1994. (Getikte manuskrip in besit van die Noordwes-Universiteit.)

VAN DER WALT, B.J. 1995. Evangelieverkondiging en/of sosiale betrokkenheid: 'n reformatoriese alternatief. Potchefstroom: Instituut vir Reformatoriese Studie. (Studiestuk 325, Januarie.)

VAN DER WALT, B.J. 2001. Why the salt has lost its quality: the influence of dualistic worldviews on Christianity. (In Van der Walt, B.J., ed. Transformed by the renewing of your mind. Potchefstroom: The Institute for Contemporary Christianity in Africa. p. 1-42.)

VAN DER WALT, B.J. 2008. A dominant form of spirituality on the African continent. (In Van der Walt, B.J. Man and God: the transforming power of biblical religion. Potchefstroom: Institute for Contemporary Christianity in Africa. p. 503-507.)

VAN DER WALT, B.J. 2009. 'n Besondere Christen en 'n unieke konferensie. (In Van der Walt, B.J. Anderkant die horison: ervaringe in verskillende wêrelddele. Potchefstroom: Private Publikasie. p. 75-85.)

VAN DER WALT, B.J. 2010. The biblical foundations and historical development of a Christian paradigm for social involvement \& a systematic exposition and practical application of a transforming Christian social philosophy. (In Van der Walt, B.J. At home in God's world. Potchefstroom: The Institute for Contemporary Christianity in Africa. p. 411-435, 436-470.) ZOKUOÉ, I. 1990. Educating for servant leadership in Africa. Africa journal of evangelical theology, 9(1):3-13. 


\section{Key concepts:}

Adeyemo, T. (1944-2010): life and work

African Christianity: present state

Evangelicalism: a typology

evangelism and social involvement, the tension between

worldview: dualistic versus integral

\section{Kernbegrippe:}

Adeyemo, T. (1944-2010): lewe en werk

Afrika-Christendom: huidige stand

Evangelikalisme: 'n tipering

evangelisasie en sosiale betrokkenheid, die spanning tussen

lewensvisie: dualisties versus integraal 